\title{
ASSOCIATION BETWEEN MDM2 SNP309 POLYMORPHISM AND ENDOMETRIal CANCER RISK IN POLISH WOMEN
}

\author{
Agnieszka Zając ${ }^{1}$, Grzegorz Stachowiak ${ }^{1}$, Tomasz Pertyński ${ }^{2}$, Hanna Romanowicz ${ }^{3}$, \\ JACEK WILCZYŃSKi ${ }^{1}$, BeATa SMOLARZ ${ }^{3}$
}

\begin{abstract}
1Department of Gynecological Surgery, Institute of Polish Mother's Memorial Hospital, Lodz, Poland 2Department of Menopausal Diseases, Institute of Polish Mother's Memorial Hospital, Lodz, Poland 3Laboratory of Molecular Genetics, Department of Pathology, Institute of Polish Mother's Memorial Hospital, Lodz, Poland
\end{abstract}

\begin{abstract}
The prognostic value of the MDM2 gene amplification/expression in many types of cancer remains unclear. Polymorphisms in the promoter region of the $M D M 2$ gene have been shown to alter the protein expression and thus, may play a role in carcinogenesis. The aim of the present study was to evaluate the association between the risk of endometrial cancer and SNP309 polymorphisms in the MDM2 gene.

The genotype analysis of SNP309 MDM2 gene polymorphisms in 152 endometrial cancer patients and 100 controls of cancer-free subjects, in the Polish population, was performed using the PCR-based restriction fragment length polymorphism (PCR-RFLP).

In the presented study, an association between MDM2 SNP309 polymorphisms and the incidence of endometrial cancer was identified. Our results obtained for the SNP309 polymorphisms of the MDM2 gene indicated that both the G/G genotype and the $G$ allele are strongly associated with endometrial cancer. We did not observe any relationship between gene polymorphism and endometrial cancer progression assessed by FIGO grade. This is the first study linking single nucleotide polymorphisms of the $M D M 2$ gene with endometrial cancer incidence in the population of Polish women.

The results support the hypothesis that the SNP309 polymorphism of the MDM2 gene may be associated with the incidence of endometrial cancer in the female population.
\end{abstract}

Key words: $M D M 2$, endometrial cancer, gene polymorphism.

\section{Introduction}

Endometrial cancer is the fourth most common carcinoma in women, and due to its growing incidence it is nowadays the leading gynecologic malignancy, especially in well-developed countries [1]. Approximately 150000 new cases are noted worldwide annually, 80\% of which being diagnosed in post menopausal patients. In the past the highest incidence was noted at the age of 57-58 years, however, recent observations confirm that the peak incidence occurs at the $6-7^{\text {th }}$ decade of life. In 2006, endometrial cancer was diagnosed in 4376 Polish women [2] and was indicated as a cause of 814 deaths, presenting as the $12^{\text {th }}$ cause of deaths among women in Poland. The share of endometrial cancer in general morbidity and mortality in our country is estimated at $7.1 \%$ and $2 \%$, respectively. Apart from age, there are plenty of recognized risk factors, especially for endometrioid endometrial cancer, including: hyperestrogenism, obesity, diabetes, hypertension, the history 
of sterility, low parity and late menopause. A growing amount of data seem to support the notion of genetic predisposition to endometrial cancer.

The human MDM2 (murine double minute) oncogene has been mapped to chromosome 12q13-14 and possesses a role of down regulator of $p 53$ suppressor gene. The product of the MDM2 gene promotes a rapid degradation of $\mathrm{p} 53$ protein, and through this mechanism protects the cell from p53-mediated growth arrest or apoptosis. It is also capable of inhibiting the p53 transactivation domain which interacts with the transcriptional machinery, resulting in p53 inactivation [3]. Furthermore, $M D M 2$ plays a regulatory role for many tumour-related genes that are important for cell-cycle control. It also contributes to carcinogenesis independently of p 53 through interaction with transcriptional factors of the E2F family, inhibition of the $\mathrm{Rb}$ growth regulatory function and inhibition of G0/G1-S-phase transition in normal cells [4-6].

In endometrial cancer tissue, p53 and MDM2 levels are correlated, suggesting that p53 is inactivated by MDM2 in endometrial cancer [7, 8]. Furthermore, Stewart et al. sequenced the TP53 gene in a series of endometrial cancer cases overexpressing p53 and found no mutations, suggesting that overexpression was due to another source such as MDM2 abnormalities [9]. $\mathrm{A} \mathrm{T} \rightarrow \mathrm{G}$ polymorphism found in the promoter region of MDM2 (SNP309) increases MDM2 expression and thereby attenuates p53 activity [10]. The variant allele of SNP309 has been associated with an earlier age at cancer diagnosis [11-14], and an increased risk of both sporadic and hereditary cancers. Terry et al. suggested that SNP309 polymorphism may be associated with the risk of endometrial cancer [15].

In the present study the association between the MDM2 SNP309 polymorphisms and endometrial cancer risk in the Polish population was investigated.

\section{Material and methods}

\section{Endometrial cancer patients}

152 patients with histologically-proven diagnosis of endometrial cancer were included in the study (Table I). Paraffin-embedded tumour tissues were obtained from postmenopausal women (mean age $64.9 \pm 8.2$ ) with endometrial carcinoma treated at the Department of Menopausal Diseases, Institute of Polish Mother's Memorial Hospital in 2004-2009. All tumours were staged according to the criteria of the International Federation of Gynaecology and Obstetrics (FIGO). DNA from normal endometrial tissue $(\mathrm{n}=100)$ served as control (mean age $54.42 \pm 19.22$ ). The Local Ethic Committee approved the study and each patient gave written consent.

The endometrial tissue samples (cancerous and noncancerous) were fixed routinely in formaldehyde, em- bedded in paraffin, cut into thin slices and stained with hematoxylin/eosin for pathological examination. DNA for analysis was obtained from an archival pathological paraffin-embedded tumour and healthy endometrial samples which were deparaffinized in xylene and rehydrated in ethanol and distilled water. In order to ensure that the chosen histological material is representative for cancerous and non-cancerous tissue, every tissue sample qualified for DNA extraction was initially checked by a pathologist. DNA was extracted from material using a commercially available QIAmp Kit (Qiagen GmbH, Hilden, Germany) DNA purification kit according to the manufacturer's instructions.

Table I. Characteristic of endometrial cancer $(n=152)$ patients

\begin{tabular}{|c|c|}
\hline CHARACTERISTICS & NuMBER OF CASES (\%) \\
\hline \multicolumn{2}{|l|}{ Age [years] } \\
\hline Median & 64 \\
\hline Range & $52-83$ \\
\hline \multicolumn{2}{|c|}{ BMI (body mass index) $\left(\mathrm{kg} / \mathrm{m}^{2}\right)$} \\
\hline$<24.9$ & $32(21 \%)$ \\
\hline $25-29.9$ & $49(32 \%)$ \\
\hline$>30$ & $71(47 \%)$ \\
\hline \multicolumn{2}{|l|}{ Number of pregnancy } \\
\hline 1 & $48(32 \%)$ \\
\hline $2-3$ & $104(68 \%)$ \\
\hline$>4$ & 0 \\
\hline \multicolumn{2}{|c|}{ Use of hormone replacement therapy (HRT) } \\
\hline Yes & $96(63 \%)$ \\
\hline No & $56(37 \%)$ \\
\hline \multicolumn{2}{|l|}{ Staging } \\
\hline $\mathrm{I}$ & $83(54 \%)$ \\
\hline II & $34(22 \%)$ \\
\hline III & $35(23 \%)$ \\
\hline \multicolumn{2}{|l|}{ Grading } \\
\hline G1 & $62(57 \%)$ \\
\hline G2 & $38(35 \%)$ \\
\hline G3 & $9(8 \%)$ \\
\hline \multicolumn{2}{|l|}{ Menopause status } \\
\hline Postmenopausal & 152 \\
\hline \multicolumn{2}{|l|}{ Uterine bleeding } \\
\hline Yes & $100(65 \%)$ \\
\hline No & $52(35 \%)$ \\
\hline \multicolumn{2}{|c|}{ Endometrial ultrasound transvaginal (TVU) } \\
\hline$>5 \mathrm{~mm}$ & $115(75 \%)$ \\
\hline Diabetes mellitus & $28(18 \%)$ \\
\hline Hypertension & $80(53 \%)$ \\
\hline
\end{tabular}




\section{Determination of $M D M 2$ genotype}

Genotypic analysis of the MDM2 SNP309 polymorphism was determined by the PCR-based restriction fragment length polymorphism (PCR-RFLP) method. Polymorphism SNP309 of the MDM2 gene was determined by PCR-RFLP, using primers 5'CGCGGGAGTTCAGGGTAAAG-3' and 5'AGCTGGAGACAAGTCAGGACTTAAC-3'. The PCR was carried out in a GeneAmp PCR system 9700 (Applied Biosystems) thermal cycler. The reaction mixture contained $5 \mathrm{ng}$ genomic. The $25 \mu \mathrm{l} \mathrm{PCR}$ mixture contained about $100 \mathrm{ng}$ of DNA, $12.5 \mathrm{pmol}$ of each primer, $0.2 \mathrm{mmol} / \mathrm{l}$ of dNTPs, $2 \mathrm{mmol} / \mathrm{l}$ of $\mathrm{MgCl}_{2}$ and $1 \mathrm{U}$ of Taq DNA polymerase (TaKaRa, Japan). The PCR cycle conditions were $94^{\circ} \mathrm{C}$ for $30 \mathrm{~s}$, $62^{\circ} \mathrm{C}$ for $30 \mathrm{~s}$, then $72^{\circ} \mathrm{C}$ for $30 \mathrm{~s}$, repeated for $35 \mathrm{cy}$ cles. The $237 \mathrm{bp}$ amplified product was digested overnight with $1 \mathrm{U}$ of MspA1I (BioLaps, New England) at $37^{\circ} \mathrm{C}$. The wild-type allele $\mathrm{T}$ was identified by the presence of $237 \mathrm{bp}$ band, while the mutant allele $\mathrm{G}$ was represented by 189 and 48 bp bands.

\section{Statistical analysis}

For each polymorphism, deviation of the genotype frequencies in the controls from those expected under Hardy-Weinberg equilibrium was assessed using the standard $\chi^{2}$-test. Genotype frequencies in cases and controls were compared by $\chi^{2}$-tests. The genotype-specific risks were estimated as odds ratios (ORs) with associated $95 \%$ intervals (CIs) by unconditional logistic regression. P-values $<0.05$ were considered to be significant.

\section{Results}

Table II shows the genotype distribution of $M D M 2$ SNP309 polymorphisms between endometrial cancer patients and controls. The Table shows that there were significant differences $(\mathrm{p}<0.05)$ between the two investigated groups. Women with endometrial cancer showed an incidence of $16 \%, 20 \%$ and $64 \%$, respectively, for the $T / T, T / G$, and $G / G$ genotypes of the MDM2 gene, whereas the control group showed $24 \%, 48 \%$, and $28 \%$ for the same genotypes. We observed an association between the endometrial carcinoma occurrence and the presence of the G/G genotypes. Variant $\mathrm{G}$ allele of $M D M 2$ increased the cancer risk. In patients, the observed frequencies of the $T / T$, $T / G$ and $G / G$ genotypes differed significantly $(p<0.05)$ from the distribution expected from the HardyWeinberg equilibrium (Table II).

Because we were interested in the association between the distribution of genotypes and frequencies of alleles of the investigated polymorphism on the tumour grade evaluated according to FIGO criteria, these

Table II. The allele and genotype frequencies and odds ratio (OR) of the SNP309 polymorphism of the MDM2 gene in patients with endometrial cancer $(\mathrm{n}=152)$ and controls $(\mathrm{n}=100)$

\begin{tabular}{|c|c|c|c|c|c|c|}
\hline \multirow[t]{2}{*}{ ENDOMETRIAL } & \multicolumn{2}{|c|}{ CANCER PATIENTS } & \multicolumn{2}{|c|}{ CONTROLS } & \multirow[t]{2}{*}{ OR $(95 \% \mathrm{CI})^{\mathrm{C}}$} & \multirow[t]{2}{*}{$P$} \\
\hline & NUMBER & $(\%)$ & NUMBER & $(\%)$ & & \\
\hline $\mathrm{T} / \mathrm{T}$ & 24 & 16 & 24 & 24 & $0.66(0.39-0.92)$ & 0.53 \\
\hline $\mathrm{T} / \mathrm{G}$ & 30 & 20 & 48 & 48 & $0.41(0.15-0.67)$ & 0.29 \\
\hline $\mathrm{G} / \mathrm{G}$ & 98 & 64 & 28 & 28 & $2.28(2.02-2.54)$ & 0.03 \\
\hline$\chi^{2}$ & \multicolumn{2}{|c|}{$8.019^{a}$} & \multicolumn{2}{|c|}{$0.245^{b}$} & & \\
\hline $\mathrm{T}$ & 78 & 26 & 96 & 48 & $0.54(0.28-0.80)$ & 0.10 \\
\hline G & 226 & 74 & 104 & 52 & $1.42(1.16-1.68)$ & 0.10 \\
\hline
\end{tabular}

${ }_{a} p<0.05$ as compared with Hardy-Weinberg distribution; ${ }^{b} p>0.05$ as compared with Hardy-Weinberg distribution; ${ }^{c}$ Crude odds ratio (OR) $95 \%$ CI - confidence interval at $95 \%$

Table III. Dependency of genotypes and frequencies of the alleles of MDM2 gene SNP309 polymorphism on the tumour stage in patients with endometrial cancer $^{\mathrm{a}}$

\begin{tabular}{|c|c|c|c|c|c|c|}
\hline \multirow[t]{2}{*}{ StAGE } & \multicolumn{2}{|c|}{$\mathrm{I}(\mathrm{N}=83)$} & \multicolumn{2}{|c|}{ II $(\mathrm{N}=34)$} & \multicolumn{2}{|c|}{ III $(\mathrm{N}=35)$} \\
\hline & NUMBER $(\%)$ & OR $(95 \% \mathrm{CI})^{\mathrm{D}}$ & NuMBER (\%) & OR $(95 \% \mathrm{CI})$ & NumbER $(\%)$ & OR $(95 \% \mathrm{CI})$ \\
\hline $\mathrm{T} / \mathrm{T}$ & $13(16 \%)$ & $0.66(0.36-0.96)$ & $10(29 \%)$ & $1.20(1.11-1.29)$ & $1(3 \%)$ & $0.12(0.01-0.48)$ \\
\hline $\mathrm{T} / \mathrm{G}$ & $13(16 \%)$ & $0.33(0.03-0.63)$ & $9(26 \%)$ & $0.54(0.45-0.63)$ & $8(23 \%)$ & $0.47(0.11-0.83)$ \\
\hline $\mathrm{G} / \mathrm{G}$ & $57(68 \%)$ & $2.42(2.12-2.72)$ & $15(44 \%)$ & $1.57(1.48-1.66)$ & $26(74 \%)$ & $1.64(1.28-2.0)$ \\
\hline $\mathrm{T}$ & $39(23 \%)$ & $0.47(0.17-0.77)$ & $29(43 \%)$ & $0.89(0.8-0.98)$ & $10(14 \%)$ & $0.29(0.01-0.65)$ \\
\hline G & $127(77 \%)$ & $1.48(1.18-1.78)$ & $39(57 \%)$ & $1.09(1.0-1.18)$ & $60(86 \%)$ & $1.65(1.29-1.91)$ \\
\hline$\chi^{2}$ & $6.463^{b}$ & & $0.001^{\mathrm{c}}$ & & $1.29 c$ & \\
\hline
\end{tabular}


Table IV. Distribution of genotypes and frequencies of the alleles of MDM2 gene SNP309 polymorphism and the endometrial cancer risk factors

\begin{tabular}{|c|c|c|c|c|c|c|}
\hline \multirow[t]{2}{*}{ BMI } & \multicolumn{2}{|c|}{$<24.99 \mathrm{KG} / \mathrm{M}^{2}(\mathrm{~N}=32)$} & \multicolumn{2}{|c|}{$25-29.99 \mathrm{KG} / \mathrm{M}^{2}(\mathrm{~N}=49)$} & \multicolumn{2}{|c|}{$>30 \mathrm{KG} / \mathrm{M}^{2}(\mathrm{~N}=71)$} \\
\hline & NUMBER & FREQUENCY & NUMBER & FREQUENCY & NUMBER & FREQUENCY \\
\hline $\mathrm{T} / \mathrm{T}$ & 8 & 0.25 & 15 & 0.31 & 12 & 0.17 \\
\hline $\mathrm{T} / \mathrm{G}$ & 5 & 0.16 & 7 & 0.14 & 13 & 0.18 \\
\hline $\mathrm{G} / \mathrm{G}$ & 19 & 0.60 & 27 & 0.55 & 46 & 0.65 \\
\hline $\mathrm{T}$ & 21 & 0.32 & 37 & 0.38 & 37 & 0.26 \\
\hline G & 43 & 0.68 & 61 & 0.62 & 105 & 0.74 \\
\hline$\chi^{2}$ & $3.683^{\mathrm{a}}$ & & $2.15^{\mathrm{a}}$ & & $3.43^{\mathrm{a}}$ & \\
\hline \multirow{2}{*}{\multicolumn{3}{|c|}{ HORMONE REPLACEMENT THERAPY (HRT) }} & \multicolumn{2}{|c|}{ YES $(\mathrm{N}=96)$} & \multicolumn{2}{|c|}{ NO $(\mathrm{N}=56)$} \\
\hline & & & NUMBER & FREQUENCY & NUMBER & FREQUENCY \\
\hline $\mathrm{T} / \mathrm{T}$ & & & 28 & 0.29 & 12 & 0.21 \\
\hline $\mathrm{T} / \mathrm{G}$ & & & 36 & 0.37 & 10 & 0.18 \\
\hline $\mathrm{G} / \mathrm{G}$ & & & 32 & 0.33 & 34 & 0.61 \\
\hline $\mathrm{T}$ & & & 92 & 0.48 & 34 & 0.30 \\
\hline G & & & 100 & 0.52 & 78 & 0.70 \\
\hline$\chi^{2}$ & & & $0.001^{\mathrm{a}}$ & & $2.74^{\mathrm{a}}$ & \\
\hline UTER & & & \multicolumn{2}{|c|}{ Metrorrhagia $(+)(\mathrm{N}=52)$} & \multicolumn{2}{|c|}{ METRORRHAGia $(-)(\mathrm{N}=100)$} \\
\hline $\mathrm{T} / \mathrm{T}$ & & & 14 & 0.18 & 21 & 0.21 \\
\hline $\mathrm{T} / \mathrm{G}$ & & & 21 & 0.05 & 21 & 0.21 \\
\hline $\mathrm{G} / \mathrm{G}$ & & & 17 & 0.77 & 58 & 0.58 \\
\hline $\mathrm{T}$ & & & 49 & 0.47 & 63 & 0.32 \\
\hline$G$ & & & 55 & 0.53 & 137 & 0.68 \\
\hline$\chi^{2}$ & & & $0.051^{\mathrm{a}}$ & & $9.68^{a}$ & \\
\hline \multicolumn{3}{|c|}{ TRANSVAGINAL ULTRASOUND (TVU) } & \multicolumn{2}{|c|}{$<5$ MM $(\mathrm{N}=37)$} & \multicolumn{2}{|c|}{$>5 \mathrm{MM}(\mathrm{N}=115)$} \\
\hline $\mathrm{T} / \mathrm{T}$ & & & 10 & 0.27 & 22 & 0.19 \\
\hline $\mathrm{T} / \mathrm{G}$ & & & 11 & 0.29 & 20 & 0.17 \\
\hline $\mathrm{G} / \mathrm{G}$ & & & 16 & 0.43 & 73 & 0.63 \\
\hline $\mathrm{T}$ & & & 31 & 0.42 & 64 & 0.28 \\
\hline G & & & 43 & 0.58 & 166 & 0.72 \\
\hline$\chi^{2}$ & & & $0.001^{\mathrm{a}}$ & & $0.169^{\mathrm{a}}$ & \\
\hline HYPEI & & & \multicolumn{2}{|c|}{ YES $(\mathrm{N}=80)$} & \multicolumn{2}{|c|}{ NO $(\mathrm{N}=72)$} \\
\hline $\mathrm{T} / \mathrm{T}$ & & & 14 & 0.18 & 11 & 0.15 \\
\hline $\mathrm{T} / \mathrm{G}$ & & & 10 & 0.13 & 15 & 0.21 \\
\hline $\mathrm{G} / \mathrm{G}$ & & & 56 & 0.70 & 46 & 0.64 \\
\hline $\mathrm{T}$ & & & 38 & 0.24 & 37 & 0.26 \\
\hline$G$ & & & 122 & 0.76 & 107 & 0.74 \\
\hline$\chi^{2}$ & & & $1.434^{\mathrm{a}}$ & & $1.350^{\mathrm{a}}$ & \\
\hline DIABE & & & \multicolumn{2}{|c|}{ YES $(\mathrm{N}=28)$} & \multicolumn{2}{|c|}{$\mathrm{NO}(\mathrm{N}=124)$} \\
\hline $\mathrm{T} / \mathrm{T}$ & & & 5 & 0.18 & 19 & 0.15 \\
\hline $\mathrm{T} / \mathrm{G}$ & & & 6 & 0.18 & 24 & 0.19 \\
\hline $\mathrm{G} / \mathrm{G}$ & & & 17 & 0.60 & 81 & 0.65 \\
\hline $\mathrm{T}$ & & & 16 & 0.29 & 62 & 0.25 \\
\hline G & & & 40 & 0.71 & 186 & 0.75 \\
\hline$\chi^{2}$ & & & $2.082^{\mathrm{a}}$ & & $3.280^{\mathrm{a}}$ & \\
\hline
\end{tabular}


data were also analyzed. Histological grades were evaluated in all the cases $(n=152)$; grade $I-83$ cases, grade II -34 cases and grade III -35 cases. Grades II and III were accounted together for statistical analysis (see Table III).

We did not observe any difference between SNP309 genotype distributions in these groups. There was no correlation between genotypes of the polymorphisms and endometrial cancer invasiveness.

No statistically significant differences were observed in the alleles or in the genotype frequencies of the MDM2 SNP309 gene polymorphisms between risk factors of endometrial cancer such as BMI (body mass index), HRT (hormone replacement therapy), uterine bleeding, endometrial ultrasound transvaginal, diabetes and hypertension and the women with endometrial cancer.

\section{Discussion}

The literature data suggest that the identification of new risk factors for endometrial cancer in a population of women is urgently needed, and an analysis of some gene polymorphisms could be an interesting option.

In the present work we investigated the frequencies of the alleles of the MDM2 SNP309 polymorphism in samples from patients with endometrial cancer and from healthy individuals. We investigated the relationship between genotype and the risk of endometrial cancer. In our study we found an association between the endometrial cancer occurrence and SNP309 polymorphism. The $M D M 2 \mathrm{G} / \mathrm{G}$ genotype and $\mathrm{G}$ allele were associated with an elevated risk of endometrial cancer in this study population. There was a 3.5-fold higher risk of endometrial carcinoma for the individuals carrying the $M D M 2-\mathrm{G} / \mathrm{G}$ genotype, compared with subjects carrying the $M D M 2-\mathrm{T} / \mathrm{T}, \mathrm{G} / \mathrm{T}$ genotype, respectively. It is possible that the presence of the $\mathrm{G}$ allele is in linkage disequilibrium with another, so far unknown, mutation located outside the coding region in the MDM2 gene, which may be of importance for the MDM2 concentration in plasma.

We also analyzed the distribution of genotypes and frequency of alleles in groups of patients suffering from endometrial cancer according to different cancer grading by FIGO classification. In the present study, the MDM2 SNP309 polymorphism was not related to the cancer grade. The reason for this can be a relatively small group of I, II and III grade cases enrolled in our study.

The effect of MDM2 polymorphism on endometrial cancer occurrence in Poland has not been investigated before.

The presented work was performed on an ethnically homogenous population, which may improve our knowledge as to what extent the genotype-phenotype relationship variations are population-related.
Our results are in line with the data from other reports, introducing an important role of the MDM2 SNP309 polymorphism for endometrial carcinoma occurrence. SNP309 polymorphisms, chosen for the study, have been identified in the 5' untranslated region of the MDM2 gene and have been shown to influence gene transcription activity [10]. It is known that single nucleotide polymorphism SNP309 in the promoter region of $M D M 2$ gene plays an important role in human tumorigenesis [16-26].

MDM2 gene SNP309 polymorphisms have been studied as a risk factor for endometrial cancer [15, 19, 27-29]. Terry et al. showed that women carrying GG genotype of MDM2 SNP309 polymorphism may be at greater risk of endometrial cancer [15]. Walsh et al. found an association between a functional single nucleotide polymorphism in the MDM2 gene and sporadic endometrial cancer risk [19].

In a large American case-control study of patients with endometrial cancer, the SNP309 G/G variant genotypes of $M D M 2$ were found to be associated with an increased risk of endometrial cancer $[15,19]$.

Similar results were reported in a Australian casecontrol study of endometrial cancer [27]. Ashton $e t$ al. suggested that the combination of the MDM2 SNP309 and the three TP53 polymorphisms appear to be related to a higher grade of endometrial cancer.

The homozygous variants of wild p 53 codon 72 and mutant MDM2 promoter 309 may cooperatively increase the risk of endometrial cancer in a Japanese population [28]. The homozygous GG genotype of SNP309 polymorphism was also associated with the postmenopausal status and type I endometrial cancer in Japanese women [29].

In conclusion, the present study provides evidence for the significance of $M D M 2$ polymorphism in endometrial cancer.

The obtained data suggest that both $\mathrm{G}$ allele and homozygous GG genotype of MDM2-SNP309 are associated with the endometrial cancer risk. Finally, it is postulated that the SNP309 polymorphism of the MDM2 gene may be used as predictive factors for endometrial cancer in Poland. Further studies conducted on a larger group are suggested to clarify this point.

The authors declare no conflict of interest.

\section{References}

1. Jemal A, Siegel R, Ward E, et al. Cancer statistics, 2009. CA Cancer J Clin 2009; 59: 225-249.

2. Wojciechowska U, Didkowska J, Zatoński W. Corpus uteri cancer. In: Zatoński W (ed.). Cancer in Poland in 2006. Department of Epidemiology and Cancer Prevention. Warszawa 2008; 30-32

3. Kubbutat MH, Jones SN, Vousden KH. Regulation of p53 stability by Mdm2. Nature 1997; 387: 299-303.

4. Martin K, Trouche D, Hagemeier C, et al. Stimulation of E2F1/DP1 transcriptional activity by MDM2 oncoprotein. Nature 1995; 375: 691-694. 
5. Xiao ZX, Chen J, Levine AJ, et al. Interaction between the retinoblastoma protein and the oncoprotein MDM2. Nature 1995; 375: 694-698.

6. Brown DR, Thomas CA, Deb SP. The human oncoprotein MDM2 arrests the cell cycle: elimination of its cell-cycleinhibitory function induces tumorigenesis. EMBO J 1998; 17 : 2513-2525.

7. Nayak MS, Yang JM, Hait WN. Effect of a single nucleotide polymorphism in the murine double minute 2 promoter (SNP309) on the sensitivity to topoisomerase II-targeting drugs. Cancer Res 2007; 67: 5831-5839.

8. Soslow RA, Shen PU, Chung MH, Isacson C. Distinctive p53 and $\mathrm{mdm} 2$ immunohistochemical expression profiles suggest different pathogenetic pathways in poorly differentiated endometrial carcinoma. Int J Gynecol Pathol 1998; 17: 129-134.

9. Stewart RL, Royds JA, Burton JL, et al. Direct sequencing of the p53 gene shows absence of mutations in endometrioid endometrial adenocarcinomas expressing $\mathrm{p} 53$ protein. Histopathology $1998 ; 33: 440-445$.

10. Bond GL, Hu W, Bond EE, et al. A single nucleotide polymorphism in the MDM2 promoter attenuates the p53 tumor suppressor pathway and accelerates tumor formation in humans. Cell 2004; 119: 591-602.

11. Bond GL, Hirshfield KM, Kirchhoff T, et al. MDM2 SNP309 accelerates tumor formation in a gender-specific and hormone-dependent manner. Cancer Res 2006; 66: 5104-5110.

12. Bougeard G, Baert-Desurmont S, Tournier I, et al. Impact of the MDM2 SNP309 and p53 Arg72Pro polymorphism on age of tumour onset in Li-Fraumeni syndrome. J Med Genet 2006; 43: 531-533.

13. Menin C, Scaini MC, De Salvo GL, et al. Association between MDM2-SNP309 and age at colorectal cancer diagnosis according to p53 mutation status. J Natl Cancer Inst 2006; 98: 285-288.

14. Hu Z, Jin G, Wang L, et al. MDM2 promoter polymorphism SNP309 contributes to tumor susceptibility: evidence from 21 case-control studies. Cancer Epidemiol Biomarkers Prev 2007; 16: $2717-2723$.

15. Terry K, McGrath M, Lee IM, et al. MDM2 SNP309 is associated with endometrial cancer risk. Cancer Epidemiol Biomarkers Prev 2008; 17: 983-986.

16. Ohmiya N, Taguchi A, Mabuchi N, et al. MDM2 promoter polymorphism is associated with both an increased susceptibility to gastric carcinoma and poor prognosis. J Clin Oncol 2006; 24 : 4434-4440

17. Dharel N, Kato N, Muroyama R, et al. MDM2 promoter SNP309 is associated with the risk of hepatocellular carcinoma in patients with chronic hepatitis C. Clin Cancer Res 2006; 12 : 4867-4871.

18. Lind H, Zienolddiny S, Ekstrøm PO, et al. Association of a functional polymorphism in the promoter of the MDM2 gene with risk of nonsmall cell lung cancer. Int J Cancer 2006; 119 : 718-721.

19. Walsh CS, Miller CW, Karlan BY, Koeffler HP. Association between a functional single nucleotide polymorphism in the MDM2 gene and sporadic endometrial cancer risk. Gynecol Oncol 2007; 104: 660-664.

20. Bond GL, Hu W, Bond EE, et al. A single nucleotide polymorphism in the MDM2 promoter attenuates the p53 tumor suppressor pathway and accelerates tumor formation in humans. Cell 2004; 119: 591-602.

21. Onat OE, Tez M, Ozçelik T, Törüner GA. MDM2 T309G polymorphism is associated with bladder cancer. Anticancer Res 2006; 26: 3473-3475.

22. Ma H, Hu Z, Zhai X, et al. Polymorphisms in the MDM2 promoter and risk of breast cancer: a case-control analysis in a Chinese population. Cancer Lett 2006; 240: 261-267.

23. Campbell IG, Eccles DM, Choong DY. No association of the MDM2 SNP309 polymorphism with risk of breast or ovarian cancer. Cancer Lett 2006; 240: 195-197.
24. Alhopuro P, Ylisaukko-Oja SK, Koskinen WJ, et al. The MDM2 promoter polymorphism SNP309T $\rightarrow \mathrm{G}$ and the risk of uterine leiomyosarcoma, colorectal cancer, and squamous cell carcinoma of the head and neck. J Med Genet 2005; 42: 694-698.

25. El Hallani S, Marie Y, Idbaih A, et al. No association of MDM2 SNP309 with risk of glioblastoma and prognosis. J Neurooncol 2007; 85: 241-244.

26. Wilkening S, Bermejo JL, Hemminki K. MDM2 SNP309 and cancer risk: a combined analysis. Carcinogenesis 2007; 28: 2262-2267.

27. Ashton KA, Proietto A, Otton G, et al. Polymorphisms in TP53 and MDM2 combined are associated with high grade endometrial cancer. Gynecol Oncol 2009; 113: 109-114.

28. Nunobiki O, Ueda M, Yamamoto M, et al. Polymorphisms of p53 codon 72 and MDM2 promoter 309 and the risk of endometrial cancer. Hum Cell 2009; 22: 101-106.

29. Ueda M, Yamamoto M, Nunobiki O, et al. Murine doubleminute 2 homolog single nucleotide polymorphism 309 and the risk of gynecologic cancer. Hum Cell 2009; 22: 49-54.

\section{Address for correspondence}

\section{Beata Smolarz}

Laboratory of Molecular Genetics

Department of Pathology

Institute of Polish Mother's Memorial Hospital

Rzgowska 281/289

93-338 Lodz, Poland

tel. +48422712071

e-mail: smolbea@wp.pl 